\title{
Genetic Diversity in Populations of Xanthomonas campestris pv. campestris in Cruciferous Weeds in Central Coastal California
}

\author{
A. Ignatov, A. Sechler, E. L. Schuenzel, I. Agarkova, B. Oliver, A. K. Vidaver, and N. W. Schaad
}

First, second, third, and seventh authors: United States Department of Agriculture-Agricultural Research Service, Foreign Disease-Weed Science Research Unit, Ft. Detrick, MD; fourth and sixth authors: Department of Plant Pathology, University of Nebraska, Lincoln; and fifth author: Monterey County Agricultural Commissioners Office, Salinas, CA.

Current address of A. Ignatov: Bioengineering RAS, Moscow, Russia.

Accepted for publication 2 February 2007.

\begin{abstract}
Ignatov, A., Sechler, A., Schuenzel, E. L., Agarkova, I., Oliver, B., Vidaver, A. K., and Schaad, N. W. 2007. Genetic diversity in populations of Xanthomonas campestris pv. campestris in cruciferous weeds in central coastal California. Phytopathology 97:803-812.

Xanthomonas campestris pv. campestris (X. campestris) infects a large number of cruciferous plants, including weeds. California has one of the largest and most diverse populations of wild cruciferous plants in the world. Although considerable information is available on the genetic diversity of $X$. campestris in commercial crop plants, nothing is known about the diversity in strains infecting weeds. To assess the genetic diversity among strains of $X$. campestris in weeds in noncultivated and cultivated areas, strains of the pathogen were isolated from populations of

cruciferous weeds growing in coastal valley crop-production sites and from remote nonproduction sites along the California central coast. Results of fingerprinting over 68 strains using amplified fragment length polymorphism along with representative strains by sequence analysis showed the presence of seven genotypes. Genotypes A and B were limited to coastal sites; genotypes C, D, and E were from inland cultivated sites; and genotypes $\mathrm{F}$ and $\mathrm{G}$ were present in both coastal noncultivated and inland cultivated sites. Crop strains were grouped outside any weed strain group and were separated from the weed strains and other pathovars of $X$. campestris. These results revealed, for the first time, that strains of $X$. campestris present in noncultivated coastal weed populations generally were unique to a site and genetically distinct from strains present in populations of weeds in crop-production areas located nearby.
\end{abstract}

Xanthomonas campestris pv. campestris (X. campestris), the causal agent of black rot of crucifers, infects a large number of cruciferous plants, including agriculturally important crops such as cabbage, broccoli, and cauliflower $(6,18,25,29)$ and many weeds (18). Little resistance to black rot is available in commercial lines $(6,25,29)$. Long-distance spread is normally by seed and transplants $(18,29)$, whereas local spread occurs mostly by wind-blown rain (9). Information about occurrence and distribution of specific strains of $X$. campestris on commercial seed is scarce, and even less is known about the biology of strains of $X$. campestris on wild crucifers.

Weedy crucifers can serve as reservoirs of inoculum near seedproduction and fresh-market fields $(6,19,29)$. California has one of the largest and most diverse populations of wild crucifers in the world. Munz (13) described over 300 species of crucifers in California and the San Diego Museum of Natural History (17) lists 87 crucifer species common to the coastal area only. The central coast has large stands of Brassica nigra L. (black mustard), Sisymbrium officinale L (hedge mustard), B. campestris L. (field mustard), B. geniculata (syn. Hirschfeldia incana, smallpod mustard), and Raphanus sativus (wild radish). Wild crucifers are often the most common weed along roads and railroads, abandoned agricultural lands, hillsides, and shorelines. Many hillsides are covered with yellow flowers (crucifers) in the early spring and, in many coastal locations, one or more crucifer species can be found year round.

Corresponding author: N. W. Schaad; E-mail address: norman.schaad@ ars.usda.gov

doi:10.1094/PHYTO-97-7-0803

This article is in the public domain and not copyrightable. It may be freely reprinted with customary crediting of the source. The American Phytopathological Society, 2007.
The presence of black rot in cruciferous weeds in vegetableproduction areas of coastal inland valleys of Lompoc, Salinas, and Santa Clara have been reported (19). However, no information is available on the presence of $X$. campestris in crucifer weeds along the Pacific coast, which are geographically isolated from commercial crops. The degree of genetic diversity among $X$. campestris strains in commercial crucifer plants is well established $(1,11,26,31)$; however, nothing is known about the amount of diversity in strains infecting cruciferous weeds. To determine the genetic diversity among strains of $X$. campestris in weeds in noncultivated and cultivated areas, strains of $X$. campestris were isolated from populations of cruciferous weeds growing in remote sites along the California central coast and from sites of current or previous fresh-market and seed-production or breeding areas of Lompoc, Salinas, Hollister, and San Juan Bautista. Several of the coastal collection sites were located $100 \mathrm{~m}$ or less from the Pacific Ocean and were geographically isolated from the inland cultivated fields by mountains.

Results of fingerprinting over 70 strains using amplified fragment length polymorphism (AFLP) showed the presence of seven genotypes among the coastal strains; all but one were unique to the coastal sites. These results reveal, for the first time, that strains of $X$. campestris present in the noncultivated coastal weed populations generally are site unique and quite different from strains present in populations of weeds found in crop-production areas.

\section{MATERIALS AND METHODS}

Collections of original strains from weeds. To obtain original cultures, a collecting trip was conducted in mid-March 2005, when cruciferous plants along the central California coast normally bloom. Several strains had been collected 2 weeks earlier (B. 
Oliver and D. Opengnorth, California Department of Food and Agriculture) from site 33 (Fig. 1). One strain, International Collection of Phytopathogenic bacteria (ICPB) 11309 (B-89) collected from black mustard in 1980 (17) near Gonzales was included for reference. Weed samples with suspect black rot symptoms were collected from both cultivated and noncultivated sites (Fig. 1). A noncultivated site was defined as an area which had never been cultivated and was located $3.2 \mathrm{~km}$ or more from any cultivated site. The collection trip began along U.S. Highway 101 in Newberry Park north of Los Angeles, extended north through Santa Barbara and Lompoc to San Luis Obispo, and then on U.S. Highway 1 along the Pacific Ocean to Salinas River Beach near Castroville and the beginning of the Salinas Valley. Collections were made in the fresh-market production areas of the Salinas Valley and the seed-breeding areas of Hollister and San Juan Bautista. Samples were collected from several beach sites near Santa Cruz and then inland at Milpitas near San Jose along I580 in Pleasanton and I-80 in Dixon, near Davis. Global positioning system locations were recorded for each site.

Beginning at Moro Bay near San Luis Obispo, U.S. Highway 1 follows the Pacific Ocean, with prevailing winds from the west and 1- to 2,000-m-high coast mountain ranges located 200 to $700 \mathrm{~m}$ to the east (Fig. 1). The foothill area along the coast has been used for cattle grazing for over 100 years and has never been cultivated. Crucifers are the dominant weeds in the early spring (March to April), with large patches occurring along the hillsides and roads.

Plant samples with suspect black rot symptoms were collected and stored in ZipLock plastic bags and put between dry papers in a plant press each evening. Plant identifications were made following Munz and Keck (13). Isolations were made onto yeast extract- $\mathrm{CaCO}_{3}$ (YDC) and Fieldhouse-Sasser (FS) agar media (20). Bacteria were isolated from some samples at California Seed and Plant Laboratory in Eleverta, and the remaining samples were processed in Fort Detrick, MD. Dry leaf samples from each site were archived. Isolations were made from leaves with black vascular veins surrounded by varying amounts of yellowing and from black spots surrounded by yellow margins. Several typical starch-positive (FS agar) yellow cultures (YDC agar) were cloned and, typically, 2 to 10 strains per site were retained and used for pathogenicity tests (20).

Pathogenicity and race identification. For routine pathogenicity tests, seedlings (two- to three-leaf-stage) of cabbage cvs.

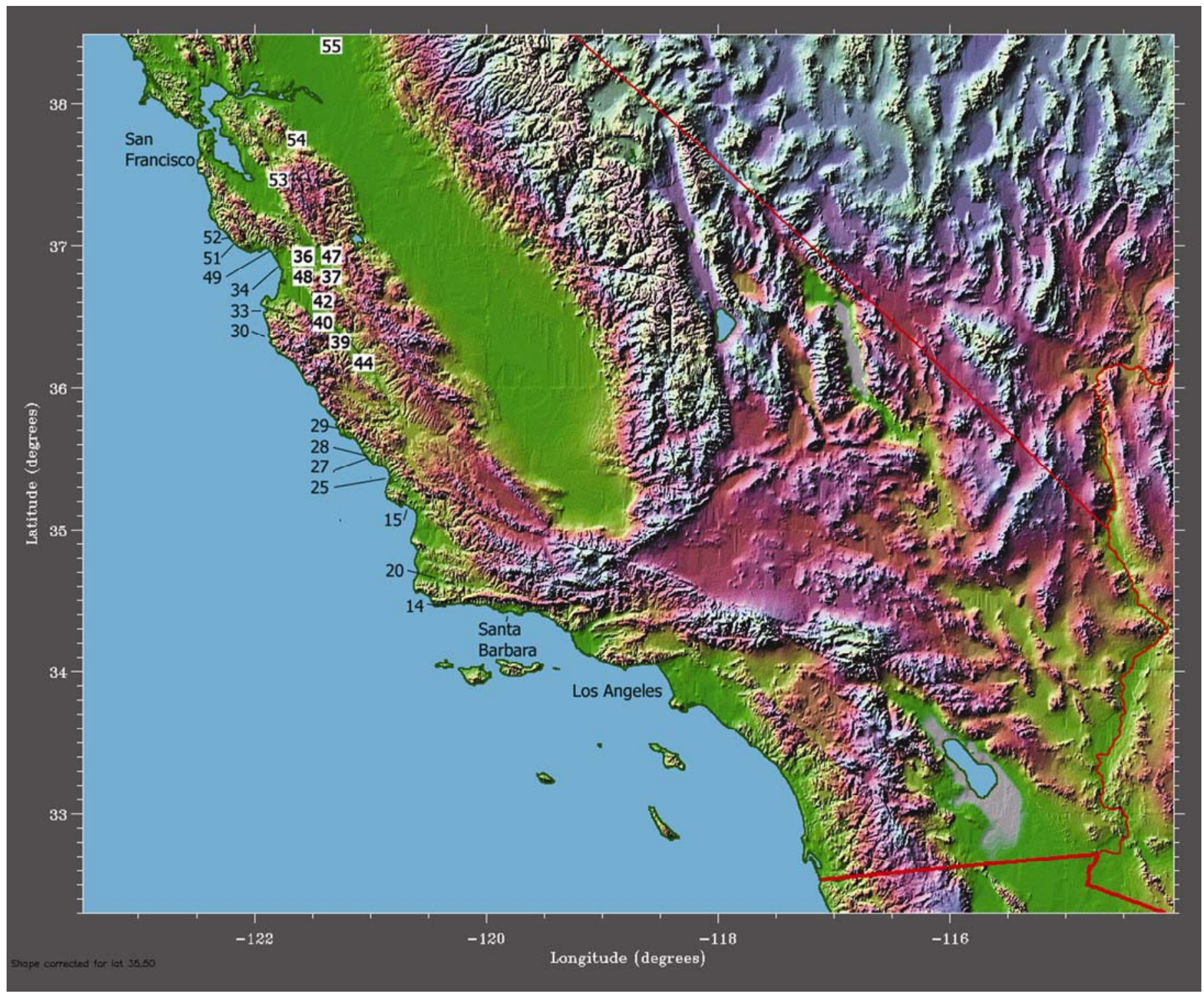

Fig. 1. Map of California showing collection sites from which strains of Xanthomonas campestris pv. campestris were isolated. Sites 14, 15, 25, 27, 28, 29, 30, 33, $34,49,51,52$, and 53 are noncultivated areas with no history of crops within 2 to $20 \mathrm{~km}$, depending upon the site. Sites 20, 36, 37, 39, 40, 42, 44, 47, 48, 54, and 55 had crops present within 1 to $2 \mathrm{~km}$, or crops were previously grown in the area. Please note the location of the site numbers are approximate; refer to Table 1 for accurate global positioning system locations. 
Pacifica $F_{1}$ and Savoy cabbage Wirosa $F_{1}$ growing on a greenhouse bench at 24 to $28^{\circ} \mathrm{C}$ were used. Bacterial cultures were grown in liquid nutrient broth yeast extract (NBY), adjusted to 0.1 optical density, diluted to contain $10^{6} \mathrm{CFU} / \mathrm{ml}$, and injected into the stem of two seedlings, as described (20). After inoculation, plants were placed on a greenhouse bench at 24 to 30 and 20 to $26^{\circ} \mathrm{C}$, day and night, respectively, with a 16 -h photoperiod. For determining pathogenicity of suspect leaf-spotting strains, seedlings were placed into a lighted dew chamber (Percival model E-54U-DL, Perry, IA) overnight at $25^{\circ} \mathrm{C}$ and the resulting guttation droplets atomized carefully with an inoculum diluted to contain $10^{7} \mathrm{CFU} / \mathrm{ml}$, as above. All pathogenic strains were added to the ICPB at Ft. Derick. The strains all were stored at $-80^{\circ} \mathrm{C}$ and, when needed, were maintained by weekly transfer on YDC agar. Races were identified using the differential cultivars described by Kamoun et al. (8) and Vicente et al. (27) and included turnip, B. rapa L. 'Just Right' $\mathrm{F}_{1}$ (Gurney's Seed, Greendale, IN), 'Tokyo Cross' $\mathrm{F}_{1}$, 'Seven Green Top' (Chas. C. Hart Seeds, Wethersfield, CN), and Indian mustard, B. juncea L. 'Florida Broad Leaf' (W. Atlas Bupee \& Co., Warminiter, PA). Seed of cauliflower $B$. oleracea L. 'Miracle' $F_{1}$ and Savoy cabbage $B$. oleracea 'Wirosa' $\mathrm{F}_{1}$ were kindly provided by Beijo Seed Co. (Oceano, CA).

For race determination tests, cultures were grown on YDC at $28^{\circ} \mathrm{C}$ for $36 \mathrm{~h}$. After suspending the cells in 4 to $5 \mathrm{ml}$ of water, 4-week-old seedlings of the differential cultivars (two- to threeleaf stage) were inoculated by puncturing the edges of leaves with a mouse tooth forceps dipped in the inoculum. In all, 8 to 10 inoculation points were made per leaf, and two to three leaves per plant were inoculated. Plants were returned to the greenhouse bench as above. Two to six plants of each differential were evaluated per strain. Each experiment was repeated three times. Results were recorded 7 and 16 days after inoculation. Plants with 1- to 2-mm-diameter black lesions at the inoculation point were rated as resistant. Plants with black lesions 5 to $20 \mathrm{~mm}$ long surrounded by varying amounts of yellowing were scored as susceptible. Race identification followed the scheme of Vicente et al. (27).

Genetic analysis. DNA isolation. For DNA extraction, bacterial cells were washed in sterile water and resuspended in $500 \mu \mathrm{l}$ of Tris-EDTA (TE) buffer. After adding $30 \mu \mathrm{l}$ of $10 \%$ (wt/vol) sodium dodecyl sulfate to lyse the cells, $100 \mu \mathrm{l}$ of $5 \mathrm{M} \mathrm{NaCl}$ was added and mixed with lysate; then, $80 \mu \mathrm{l}$ of $10 \%$ cetyltrimethylammonium bromide was added and the mixture incubated for $10 \mathrm{~min}$ at $65^{\circ} \mathrm{C}$. Lipids and proteins were removed with chloroform (1:1). After centrifugation at $12,000 \times g$ for $5 \mathrm{~min}, 400 \mu \mathrm{l}$ of the aqueous phase was transferred to a new microfuge tube and DNA was precipitated by addition of $96 \%$ ethanol (2:1). The precipitate was washed twice in $70 \%$ ethanol and dissolved in $100 \mu \mathrm{l}$ of TE buffer. DNA concentration and purity were estimated by fluorescence intensity at 260 to $280 \mathrm{~nm}$ using a Nanodrop ND-1000 (Wilmington, DE) spectrophotometer, and adjusted by sterile water to $20 \mathrm{ng} / \mu \mathrm{l}$.

AFLP analysis. The AFLP analysis (28) was carried out as described previously for Xanthomonas spp. $(16,22)$. Preliminary tests of different primer sets using a combination of MseI+C (5'GAT GAG TCC TGA GTA AC-3') and EcoRI+0 (5'-GAC TGC GTA CCA ATT C-3') resulted in 60 to 80 highly resolved bands. The EcoRI+0 primer was labeled with an infrared fluorescent dye IRDye 700 (Li-Cor Inc, Lincoln, NE). The separation of amplified products was done on a $6.5 \%$ polyacrylamide gel in a LICOR Long ReadIR DNA Sequencer (Li-Cor model 4200) and the electrophoresis image data were collected automatically and recorded in a digital format during the run. To determine genetic differences between strains, gel profiles were analyzed using GelCompar II software (Applied Maths, Kotrijk, Belgium). Gels were normalized by including LiCor's 50- to 700-bp Sizing Standard (18 DNA fragments) in each gel, and only the 145- to 700-bp area was analyzed. An optimization setting of $0.1 \%$ and a tolerance setting of $0.2 \%$ were applied to the analysis. Gels were run for all strains from each site and each gel was repeated at least twice. Twenty representative weed strains were included in a single gel to illustrate the different genotypes.

The following known cultures of $X$. campestris obtained primarily from the ICPB, American Type Culture Collection (ATCC; Manassas, VA) and National Collection of Plant-Pathogenic Bacteria (NCPPB; York, England) were included for reference: X. campestris ICPB 10451 (type strain NCPPB 528 ${ }^{\mathrm{T}}$, ICMP 13, ATCC 33913, Collection Microorganisms Gent [LMG] 568, representative for serotype/haplotype 3, England) (1), 11221 (LMG 8004, NCPPB 1145, England), 10419 (ATCC 43304, Oregon, U.S.A.), 10322 to 10325 (Georgia, U.S.A., cabbage transplants), 11349 (PHW231, U.S.A., representative for serotype/ haplotype 1) (1,26), 11518 (Xc-2, China), 10326 (FB1011, Alabama, U.S.A.), 11572 (B1, California, U.S.A., Brussels sprouts), 11309 (B-89, California, U.S.A.), and 11216 (2D520, California, U.S.A., cauliflower). Strain 11565 (BrSp2, isolated in September 2005 from a Brussels sprout plant in a commercial field near Castroville, close to site 34 ), was provided by S. Koike. Strains of other pathovars of $X$. campestris, including X. campestris pv. raphani $11195\left(\mathrm{NCPPB}_{1946} \mathrm{~T}\right) ;$ X. campestris $\mathrm{pv}$. barbareae 11391 (ICPPB XB2, ATCC 13460, NCPPB 983, LMG 547); X. campestris pv. armoraciae 10366 (NCPPB 1930) and 11196, (Xa5, The Netherlands); X. campestris pv. aberrans 11392 (NCPPB 2986 ${ }^{\mathrm{T}}$ ); and X. campestris pv. incanae 10514 (NCPPB 937 ${ }^{\mathrm{T}}$ ), LMG 7490, INRA 10905, ATCC 13462, ICMP 574, and ICPB XI 4 also were included. X. citri subsp. citri $(21,22) 10518$ (ATCC 49118) was included as an out group.

The genotypic diversity $(G)$ was calculated as $G=1 / n \mathrm{~g}_{j}^{2}$, where $\mathrm{g}_{j}$ is the frequency of the $j$ th genotype and $n$ is the total number of strains. For each locus, heterogeneity of the marker frequency was calculated by the likelihood ratio $\left(G^{2}\right)$, based on a null hypothesis of no differences in allele frequencies between populations. The $G_{\mathrm{ST}}$, defined as the proportion of total genetic diversity attributable to population differentiation, with $G_{\mathrm{ST}}=\left(H_{\mathrm{T}}-H_{\mathrm{S}}\right) / H_{\mathrm{T}}$ (where $H_{\mathrm{T}}$ is mean diversity for entire population and $H_{\mathrm{S}}$ is mean diversity within subpopulations), was calculated for strains from weeds and cultivated crops as described (14). The Ewens-Watterson test (10) for neutrality was performed on gene frequencies within strains of Californian populations to detect the possible effects of selection on allele distribution. Calculation of these and other genetic parameters of the population, such as an effective number of alleles and a number of polymorphic loci, was based upon POPGENE 1.31 program (30). The genetic distances between strains were calculated by Pearson's correlation, simple difference, and cosine algorithms (14). The resulting arrays of bands were analyzed separately for each AFLP gel and dendrograms generated by Single Linkage for all three distances. Groups were verified by k-means clustering (12) (Table 1).

Sequence analysis. Thirty-four of the California weed strains and five representative crop strains of $X$. campestris $10451^{\mathrm{T}}$, $10324,10325,11221$, and 10419 were used to construct a phylogeny based on nucleotide data. A concatenated data set of three conserved genes was used. Primers were designed from the ge-

TABLE 1. Summarized parameters of genetic variation in seven Xanthomonas campestris pv. campestris populations (A-G) from Brassica weeds

\begin{tabular}{lll}
\hline Genetic diversity & $\mathrm{Mean}^{\mathrm{a}}$ & $\mathrm{SE}^{\mathrm{b}}$ \\
\hline Within subpopulation & 0.217 & 0.006 \\
Entire population & 0.32 & 0.009 \\
Among population & 0.100 & 0.006 \\
Coefficient of differentiation & 0.32 & 0.01 \\
\hline
\end{tabular}

a Mean value for five experiments (amplified fragment length polymorphism gels).

b Standard error (SE) calculated by bootstrap at 500 replications. 
nomic sequence of $X$. campestris strain $10451^{\mathrm{T}}$ (AE008922) using Primer Express 3.0 (Applied Biosystems, Foster City, CA). The genes used were a transcriptional activator protein (XCC2818, forward: 5'-AGG GAT TCC AGT CGC TGG TG-3', reverse: 5'TTC AGA TGC AGG TTC ACG GTG-3'), ribonucleosidediphosphate reductase subunit $\beta$ (XCC3985, 5'-AAC GAC ATT CCG TAC CCG TC-3', 5'-CAC GTA ATC GGT GAG CTG GTC3'), and adenylosuccinate synthetase (XCC1053, 5'-ATG AAG GCA AAG GCA AGA TCG-3', 5'-ACA GTG GTG TTG GAG CTG GTG A-3'). Each reaction mixture contained $2 \mu$ of DNA template, $1 \times$ buffer solution (New England Biosciences), $1 \mathrm{mM}$ deoxynucleotide triphosphates, $1 \mu \mathrm{M}$ each primer, and $5 \mathrm{U}$ of Taq polymerase (New England Biosciences) for a total of $25 \mu \mathrm{l}$. The thermocycler (Thermo Hybaid, Thermo Fisher Scientific, Waltman, MA) reaction conditions were an initial denaturation at $95^{\circ} \mathrm{C}$ for $3 \mathrm{~min}$; followed by 35 cycles of $95^{\circ} \mathrm{C}$ for $30 \mathrm{~s}, 58^{\circ} \mathrm{C}$ for $30 \mathrm{~s}$ for annealing, and $72^{\circ} \mathrm{C}$ for $30 \mathrm{~s}$ for extension; with a final extension at $72^{\circ} \mathrm{C}$ for $5 \mathrm{~min}$. Polymerase chain reaction (PCR) amplification products were cleaned with Exo-Sap-It (USB Corporation, Cleveland, $\mathrm{OH}$ ). Sequencing was performed by the U.S. Department of Agriculture (USDA) Eastern Regional Research Center using the Big Dye Terminator kit with an ABI Prism 377 DNA sequencer.

The sequences were aligned with BioEdit v5.0.9 (3). A maximum likelihood (ML) tree was constructed with PAUP* version 4 (24) using the following options: the general time reversible model of molecular evolution and an invariant sites parameter (23). Additionally, a neighbor-joining bootstrap $(n=$ 500 replicates) and Bayesian analyses were performed. Bayesian analyses were performed with MrBayes 2.01 (4) with a GTR+ invariant sites model of molecular evolution, 1,000,000 generations with burn in after 200,000, four simultaneous Markov chains (three heated and one cold), and random starting trees. Sequences used for the construction of the phylogenetic tree have been deposited in GenBank under the accession numbers EF017821 to EF017937, except for those already available;
$X$. campestris strain 11221 (NC 007086) and X. citri pv. citri 10518 (AE008923).

\section{RESULTS}

Collections of specimens with black rot symptoms and bacterial cultures. The species of wild crucifers observed with symptoms of black rot included B. nigra, B. campestris, B. napus L. (rape), R. sativus , B. geniculata, B. tournefortii Gouan (Asian mustard), and $S$. officinale (Table 2). B. nigra was the most dominant crucifer found with black rot. Although multiple species were observed with black rot symptoms at many sites, isolations typically were made from only the most dominant species.

The climatic conditions were ideal for collecting black rot samples. The winter season of 2004-05 in California had been much wetter than normal and it rained intermittently during the collection; symptoms often were very evident. The first crucifer populations checked for symptoms of black rot were at the Newberry Park weigh station on U.S. 101 south of Ventura. Subsequent observations taken along U.S. 101 at Camboro Road and Refgo State Park were negative. Symptoms of black rot were first observed in B. nigra along U.S. 101 near Gaviota (site 14), $\approx 25 \mathrm{~km}$ west of Santa Barbara in a cattle-grazing area. Black rot was found in populations of B. nigra located along U.S. 101 at El Campo Road just south of Arroyo Grande in a road maintenance area (site 15). In the fresh-market and vegetable- or flower-seedproduction area of Lompoc, black rot was found in a large population of $B$. campestris growing in a farmer's crop residue site along a creek bordering Vandenberg Air Force base (site 20). The site was adjacent to several large cauliflower production fields. Several sites just east of Lompoc were negative, including a field of stock. The next site (site 25) with symptoms of black rot (Fig. 2A, upper left) contained a population of B. nigra in a cattlegrazing area adjacent to the Army Prison (Camp San Luis Obispo) $100 \mathrm{~m}$ from U.S. 1 and 2 to $3 \mathrm{~km}$ before Moro Bay. A population of B. nigra with black rot symptoms was located along

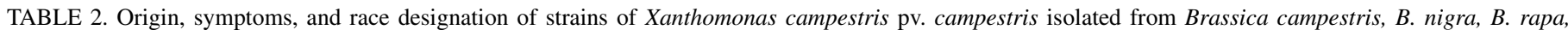
B. tournefortii, Hirschfeldia incana, Sisymbrium officinale, and Raphanus sativus in California in March 2005

\begin{tabular}{|c|c|c|c|c|c|c|c|}
\hline Site & $\begin{array}{l}\text { No. of } \\
\text { strains }\end{array}$ & Source host & Area $^{a}$ & City, location & GPS site location $^{\mathrm{b}}$ & $\begin{array}{c}\text { Original } \\
\text { symptoms }^{\mathrm{c}}\end{array}$ & Race $^{\mathrm{d}}$ \\
\hline 14 & 1 & B. nigra & $\mathrm{nc}$ & Gaviota, U.S. 101 & Not recorded & BR LS & nt \\
\hline 15 & 1 & B. nigra & nc & Arroyo Grande & $35: 06: 40 / 120: 33: 41$ & BR LS & 5 \\
\hline 20 & 5 & B. campestris & $\mathrm{c}$ & Lompoc & $34: 40: 46 / 120: 31: 18$ & BR LS & 5,6 \\
\hline 25 & 4 & B. nigra & $\mathrm{nc}$ & Moro Bay, U.S. 1 & $35: 20: 86 / 120: 44: 42$ & $\mathrm{BR}$ & 6 \\
\hline 27 & 6 & B. nigra & $\mathrm{nc}$ & Cayucos, U.S. 1 & $35: 26: 58 / 120: 55: 35$ & BR & 6 \\
\hline 28 & 3 & S. officinale & $\mathrm{nc}$ & Harmony, U.S. 1 & $35: 29: 59 / 121: 00: 37$ & BR LS & 5 \\
\hline 29 & $6^{\mathrm{e}}$ & S. officinale & $\mathrm{nc}$ & Pt. Lopez, U.S. 1 & $35: 41: 59 / 121: 17: 46$ & BR LS & $1,3,5,6$ \\
\hline 30 & 2 & B. campestris & $\mathrm{nc}$ & Big Sur, U.S. 1 & $36: 17: 53 / 121: 52: 13$ & BR & 5,6 \\
\hline 33 & 7 & S. officinale & nc & Garrapato Beach, U.S. 1 & $36: 28: 16 / 121: 56: 01$ & BR LS & $1,3,5$ \\
\hline 34 & 3 & H. incana & $\mathrm{nc}$ & Salinas River Beach & $36: 46: 18 / 121: 47: 51$ & BR BV & 6 \\
\hline 36 & 1 & $R$. sativus & $\mathrm{c}$ & Salinas, U.S. 101, Potter & $36: 36: 17 / 121: 33: 21$ & $\mathrm{BR}$ & nt \\
\hline 37 & 4 & H. incana & $\mathrm{c}$ & Salinas, Old Stage Road & $36: 39: 21 / 121: 32: 33$ & BR LS & 5 \\
\hline 39 & 4 & B. tournefortii & $\mathrm{c}$ & Gonzales, Gloria Road & $36: 30: 39 / 121: 21: 35$ & BR LS & 5,6 \\
\hline 40 & $7^{\mathrm{e}}$ & H. incana & $\mathrm{c}$ & Gonzales, Gloria Road & $36: 30: 47 / 121: 20: 43$ & BR & 6 \\
\hline 42 & 4 & S. officinale & $\mathrm{c}$ & Gonzales, Road 146 to Pinnacles Monument & $36: 25: 34 / 121: 13: 44$ & $\mathrm{BR}$ & 6 \\
\hline 44 & 4 & H. incana & $\mathrm{c}$ & Soledad, River Road & $36: 23: 59 / 121: 22: 27$ & BR LS & 6 \\
\hline 47 & 4 & B. nigra & $\mathrm{c}$ & Hollister, Hwys 25 and 156 & $36: 53: 33 / 121: 25: 39$ & $\mathrm{BR}$ & $\mathrm{nt}$ \\
\hline 48 & 1 & B. campestris & $\mathrm{c}$ & San Juan Road, Hwy 129, U.S. 101 & $36: 52: 60 / 121: 33: 27$ & BR & $\mathrm{nt}$ \\
\hline 49 & 3 & $R$. sativus & nc & Aptos, Seacliff Beach & $36: 58: 20 / 121: 54: 45$ & BR & 6 \\
\hline 51 & 5 & R. sativus & $\mathrm{nc}$ & Santa Cruz Lighthouse Beach & $36: 57: 12 / 122: 01: 31$ & BR LS & 4,5 \\
\hline 52 & 1 & $R$. sativus & nc & Natural Bridges Beach & $36: 57: 04 / 122: 03: 21$ & BR LS & 6 \\
\hline 53 & 2 & B. nigra & nc & Millpitas, Calvaras Road & $37: 26: 20 / 121: 58: 08$ & BR & 1,6 \\
\hline 54 & 4 & B. nigra & $\mathrm{nc}$ & Pleasanton, I-680 & $37: 39: 21 / 121: 53: 56$ & BR LS & $1,4,5,6$ \\
\hline 55 & 2 & B. nigra & $\mathrm{c}$ & Dixon, I-80, West A & $38: 26: 47 / 121: 51: 16$ & $\mathrm{BR}$ & nt \\
\hline
\end{tabular}

a Description: $\mathrm{nc}=$ noncultivated area and c = cultivated crops, including Brassica $\mathrm{spp}$.

b Global positioning satellite (GPS) site can be found on online.

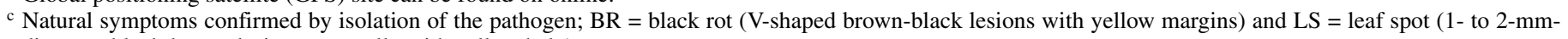
diameter black-brown lesions, normally with yellow halo).

${ }^{\mathrm{d}}$ Races are given according to Vicente et al. (27); nt = not tested.

e Not all strains typical. 
both sides of U.S. $1200 \mathrm{~m}$ from the Pacific Ocean and 1 to $2 \mathrm{~km}$ north of Cayucos, where U.S. 1 narrows to two lanes (Fig. 2, lower, site 27). A population of $S$. officinale located along U.S. 1 , 4 to $5 \mathrm{~km}$ north at Harmony ( $\approx 1 \mathrm{~km}$ inland from the ocean) had symptoms of black rot (site 28). Symptoms of leaf spotting along with brown, V-shaped lesions were observed in a population of $S$. officinale at the vista point at Point Lopez just beyond Arroyo de Orsa and just above the Pacific Ocean (Fig. 2, upper right, site 29). Point Lopez is midway between Moro Bay and Monterey. Black rot was present in B. campestris along U.S. 1 at milepost 70 just north of Big Sur (site 30) and in S. officinale at Garrapata State Beach $\approx 5 \mathrm{~km}$ south of Carmel (site 33). The disease was widespread in $H$. incana at Salinas River Beach west of Castroville (site 34). This area is the beginning of the Salinas Valley, where commercial crucifer crops are grown year round. Collections with black rot symptoms were made in $R$. sativus at Rosehart Way and Potter Rd. along U.S. 101 just south of Salinas (site 36) and in H. incana along Old Stage Road just east of Salinas airport (site 37), adjacent to fresh-market crucifer fields. Black rot was common in B. tournefortii near Gonzales along Gloria Road at Camphora Road (site 39) and in H. incana $1 \mathrm{~km}$ further east (site 40), closer to fresh-market crucifer fields. Symptoms of black rot were widespread in S. officinale along Highway 146 in a cattle-grazing area $9 \mathrm{~km}$ east of Gonzales in the foothills near Pinnacles National Monument (site 42). The nearest vegetable production was 2 to $3 \mathrm{~km}$ west toward Gonzales. Infected $H$. incana plants were found near fresh-market crucifer fields along River Road $5 \mathrm{~km}$ west of Soledad (site 44). The next collections were made north in a seed-breeding or production area in the southern part of the Santa Clara Valley between Salinas and San Jose. Collections of $B$. nigra with systemic black rot symptoms were made at the intersection of Highways 25 and 156 near Hollister (site 47), and in B. napus and B. rapa along San Juan Road just before U.S. 101 and Highway 129, 2 to $3 \mathrm{~km}$ northwest of San Juan Bautista (site 48). Symptoms of black rot were present in $R$. sativus plants adjacent to the ocean at Seacliff State Beach in Aptos (site 49) just south of Santa Cruz, and in a large population of $R$. sativus in Lighthouse Park (surf point, site 51) in Santa Cruz. Also, black rot was found in R. sativus in Natural Bridges Beach (site 52) just north of Santa Cruz. A site in Milipitas (northeast of San Jose) along Calaveras Road just beyond Evans road (cattle-grazing area just beyond residential houses in the foothills east of Milipitas) toward Calaveras Park contained many infected B. nigra plants (site 53). An abandoned weedy area (previously farmed) at Bernal Avenue along I-680 just before I-580 in Pleasanton (site 54) had many infected B. nigra plants. A large population of brassicas was found along I-580 (cattle-grazing area) 3 to $4 \mathrm{~km}$ beyond Benicia, but no symptoms were found. A large population of infected B. nigra plants was found in an open area between two new fast-food restaurants at the Dixon I-80 off ramp (West A) in a crop-production area just west of Davis (site 55). The following sites contained uninfected species: site 20, B. nigra; site 28, B. nigra and $H$. incana; site 34, $B$. campestris; site $39, B$. nigra and $B$. napus; site $42, H$. incana and $B$. rapa; site 48, B. rapa and B. napus; site 49, H. incana; site 52, $H$. incana; and site $54, H$. incana.

Pathogenicity and race structure. All cultures isolated as suspect $X$. campestris produced either systemic or leaf spot lesions (Table 2) and all strains isolated from systemic black rot lesions or leaf spot lesions caused typical black rot in at least one differential variety under glasshouse conditions. Several strains from sites 20 and 29 produced leaf spots on cvs. Wirosa, Miracle, and Seven Top Green (data not shown). The majority of the tested strains belonged to either race $6(70 \%)$ or race $5(18 \%)$. Less than $12 \%$ of the strains belonged to the races 1,3 , and 4 , or races differed from the previously recognized ones (26). The more uncommon races were found only at sites 29 (races 1, 3, 5, and 6), 33 (races 1, 3, and 5), 51 (races 4 and 5), and 54 (races 1, 4, 5, and 6) (Table 2). According to these preliminary results, strains of races 6 and 5 were highly aggressive on Chinese cabbage, turnip, and mustard when using a natural inoculation method by spraying plants with guttation droplets in a lighted dew chamber. However, in most cases, these strains (races 6 and 5) failed to penetrate hydathodes of cabbage plants, despite being highly aggressive following wound inoculation.

Genetic analysis. AFLP. Five AFLP gels with different strain sets, including at least 7 of the 15 reference $X$. campestris strains and 68 of the 84 strains from weedy brassicas, were analyzed by GelCompar II. These gels revealed from 40 to 119 bands depending upon the strain, with up to 236 total polymorphic AFLP loci with two alleles (1/0) per gel under the tolerance setting of $0.2 \%$ for the band position. A typical AFLP gel showing representative strains from most collection sites and five representative crop strains is shown in Figure 3.

The observed number of alleles in weed strains was 1.97 (standard error $[\mathrm{SE}]=0.16$ ), and the effective number of alleles was equal to $1.41(\mathrm{SE}=0.27)$. The gene diversity was $0.33(\mathrm{SE}=$ 0.01 ) and number of polymorphic loci was $96.97 \%$. The $G_{\mathrm{ST}}$ (proportion of total genetic diversity attributable to population differentiation) for the six subgroups (Table 3) was 0.32 ( $\mathrm{SE}=$ 0.01) (Table 1), indicating a comparatively low degree of differentiation among the weed strain subpopulations. The EwensWatterson test for neutrality (10) calculated for the weed population indicated that most of the putative loci in the Californian population (94.4\%) had the pattern of allele frequencies with significant probability of occurring by chance. The group of strains from cultivated crops was not large enough to give reliable estimations for the genetic parameter.

Using single-linkage analysis for cosine distance, Pearson's correlation, and simple difference, seven distinct genotypes from A to $\mathrm{G}$ (Fig. 3) were defined based upon a similarity of $\geq 68 \%$ for the obtained range of genetic distances or high bootstrap value $(>50 \%)$. The three different genetic distances generated trees with branches containing the same strains and only slight differences in similarities between the branches. Each of 68 weed strains was

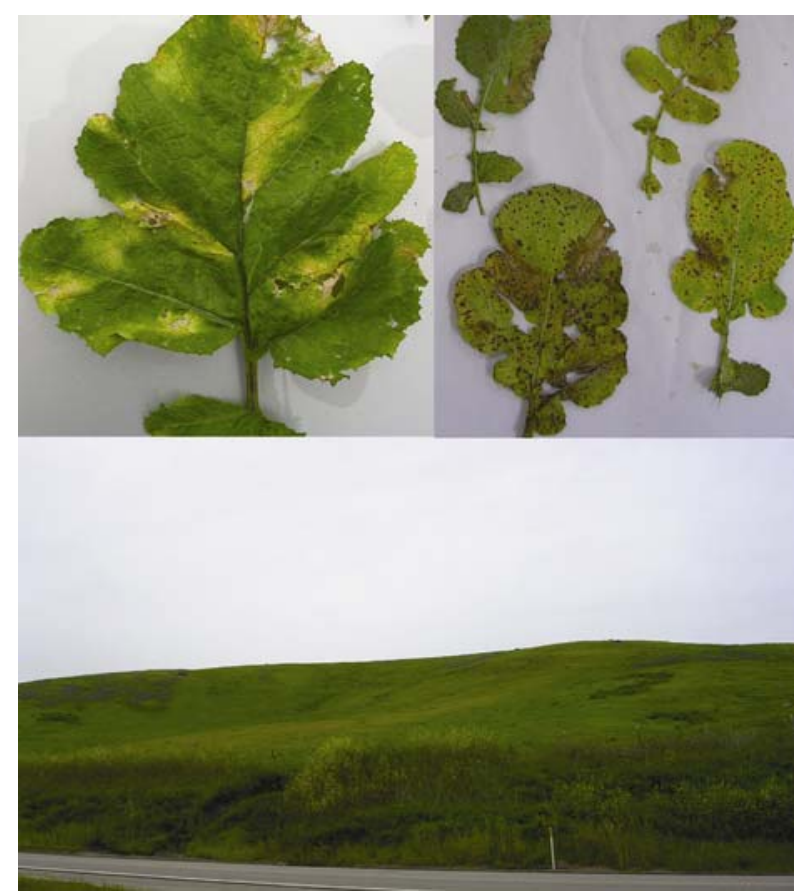

Fig. 2. Classical black rot symptoms on leaf of Brassica nigra (upper left) and leaf spotting and brown blight-like symptoms on Sisymbrium officinale (upper right) collected from site 25 and site 29, respectively. Lower figure shows a population of $B$. nigra growing between U.S. Route 1 and a cattle-grazing area in Cayucos (site 27). The Pacific Ocean is immediately behind. 
placed into one of seven genotypes by $k$-mean analysis based on results of three to five different AFLP runs and assigned to the groups $A$ to $G$ based on reference strains present in all runs (Table 3).

Genotype A strains were found in five noncultivated sites (sites 15, 25, 27, 28, and 29), all located along the Pacific Ocean, one noncultivated site in the foothills just beyond the eastern edge of the city limits of Milpitas (site 53) near San Jose, and one cultivated site near Gonzales (site 40) in the Salinas Valley (Fig. 1). Genotype B was found in the nonproduction sites at Garrapata State Beach (site 33), Big Sur (site 30), Gaviota (most southern site 14), and the foothills along Highway 146 east of Gonzales (site 42). Except for site 42, these sites all are adjacent to the Pacific Ocean. Genotype $\mathrm{C}$ was present in two cultivated sites in the Salinas Valley; site 39 at Camphora and Gloria roads in Gonzales and site 37 at Old Stage Road. Genotype C also was found at nonproduction sites 29 at Pt. Lopez, Vista Point, site 34 at Salinas River Beach, and site 42 at Gonzales, Highway 146. Genotype D was found only at site 44 along the foothills of the Salinas Valley west of Solidad. Genotype E was found at site 54 in a previously cultivated area near I-680 and I-580 in Pleasanton and at site 55 in a cultivated area just off I-80 in Dixon (Fig. 1; Table 3). This genotype included strain 11216 isolated from a commercial crop in 1955 (data not shown). Genotype F was present in several sites, including site 20 , a waste area adjacent to a commercial crucifer field along the border with Vandenberg Air Force Base west of Lompoc (a major flower- and crucifer-seedproduction area); site 47, a commercial crucifer-production area at Highway 25 and 156 near Hollister; site 48, San Juan Road at U.S. 101; site 49, a nonproduction area at Sea Cliff Beach in Aptos; and site 51, Light House State beach in Santa Cruz. Sites 51 and 52 at Natural Bridges Beach in Santa Cruz along with site 36 at Salinas/101/Potter near commercial crucifers, contained genotype $\mathrm{G}$.

All known strains of X. campestris, except strain 11216, obtained from international collections, and all strains of other pathovars of $X$. campesris from brassica crops, including $X$. campestris pvs. armoraciae, raphani, incanae, and barbareae, were clustered separately from any weed strain (Fig. 3). Crop strains were separated into two groups containing strains representative of genotypes (haplotypes) 1 and 3 recognized previously by restriction fragment length polymorphism (RFLP) (1) and repetitive element (rep)-PCR (26). Crop strain 11565, isolated in September 2005 near weed site 34, was in a group containing only known crop strains.

Phylogenetic analysis. The concatenated data set of 1,620 bp for 40 strains yielded a phylogeny that grouped the major California weeds strains by genotype (Fig. 4; Table 3) and agreed with the AFLP data (Fig. 3). All six site 27 genotype A strains grouped tightly together, except strain 27-10 (Fig. 4), which

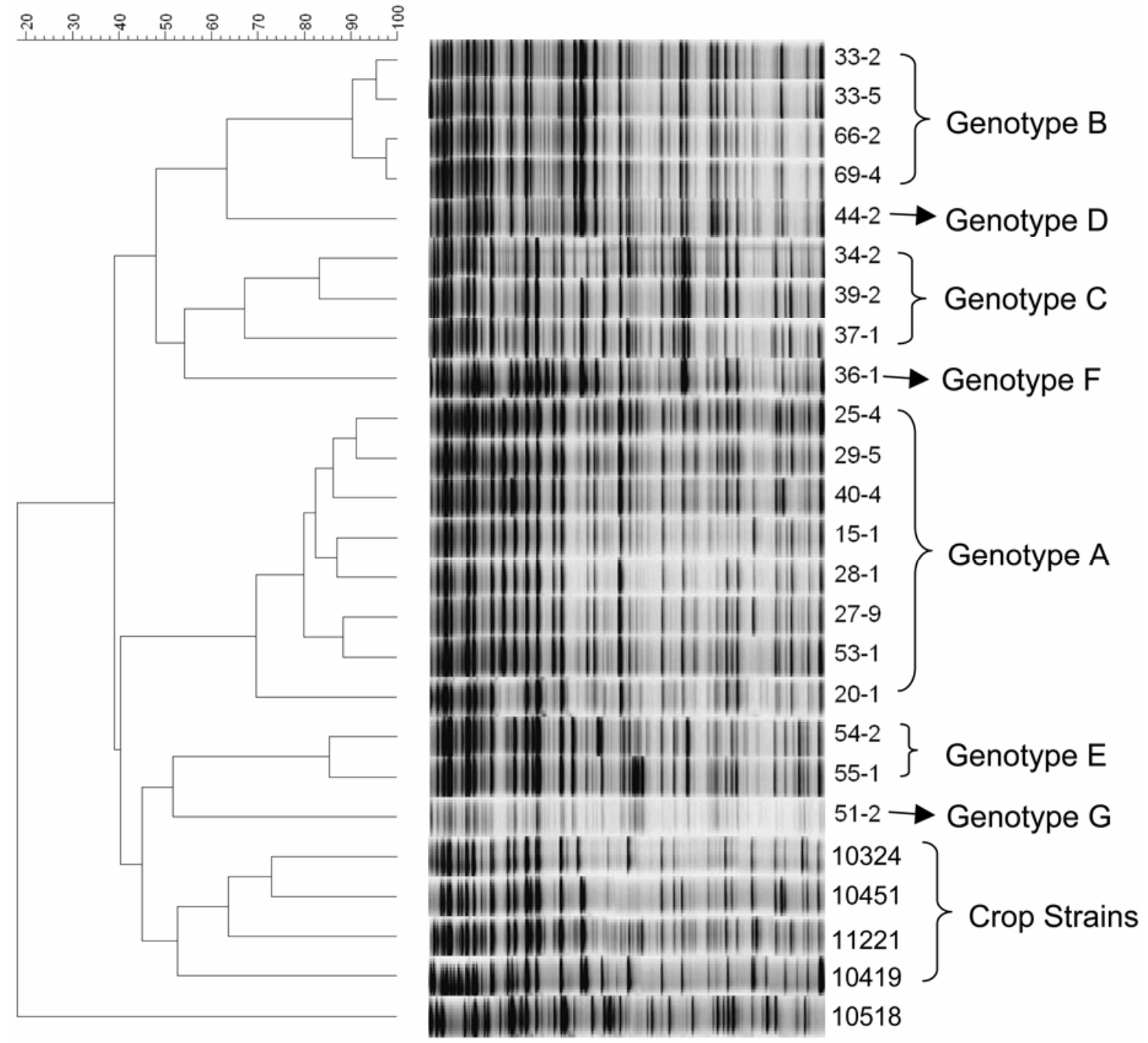

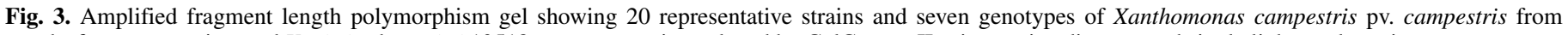
weeds, four crop strains, and X. citri subsp. citri 10518 as an out strain analyzed by GelComparII using cosine distance and single linkage clustering. 
differed by 2 bp. All genotype B strains grouped together. Strains of genotype $\mathrm{C}$ formed a single clade; seven of the strains were identical and three (29-2, 39-3, and 42-1) had slight differences. Finally, genotype E strains formed a clonal group close to but separate from the $\mathrm{C}$ strains. Complete data sets for strains classified as D, F, and G were not available. All the crop strains were different from the weed strains.

\section{DISCUSSION}

Crucifers were observed to be among the most dominant flowering plant along the Pacific Ocean in the area surveyed. Large populations were observed along roadsides, and fence lines and hillsides often were covered with yellow crucifer flowers. Random stops often resulted in the discovery of symptoms of black rot on B. nigra, $R$. raphanistrum, $S$. officinale, and $H$. incana. Generally, populations of crucifers in crop-production areas were quite small, with plants being limited to fence lines or roadsides. Evidence of the use of herbicides for weed control was common along ditch banks in production areas.

Races 1 and 4 of $X$. campestris are predominant among the strains from cultivated brassicas all over the world $(6,26)$, whereas races 5 and 6 (formerly race 0 , designated by Kamoun et al.) (8) are found mostly in B. rapa and mustard in locations with vast native populations of brassicas, such as Portugal (27). Thus, presence of $X$. campestris races 5 and 6 on weedy populations with resistance similar to $R x c \mathrm{c} 1$ in $B$. nigra, B. carinata, and $B$. juncea $(6,25)$ was expected from previous reports, but the frequency of those races was unexpectedly high. This suggests that races 5 and 6 are the ancestral states for natural populations of $X$. campestris, and other races arose due to mutations (7) or accumulation of additional avirulence genes via horizontal gene transfer. This is supported by recent results of Castaneda et al. (2). Races 5 and 6 are rare on widely cultivated crops of $B$. oleracea $(6,27)$, although they are virulent on those plants after inoculation. It is possible that the suggested additional avirulence loci (2) are responsible for adaptation to $B$. oleracea, the major cultivated species of brassicas. Strains of other races were found in low frequency $(<12 \%)$, and several strains differed from those described by Vicente et al. (27), suggesting a larger number of races in the $X$. campestris population $(6,27)$.

Schaad and Dianese (19) surveyed weeds for black rot in the Lompoc and Salinas region in 1981, and isolated X. campestris from $B$. nigra, $B$. campestris, $R$. sativus, $B$. geniculata, and B. rapa. Those black-rot-positive sites were located adjacent to cultivated brassica seed crops. One strain, 11309 (B-89), from the 1981 study, isolated from black mustard near site 44 and still available in the collection at University of Idaho, typed as genotype A. Lack of high similarity between the coastal weed population and any known crop strain suggests a natural presence of the pathogen population in weeds, possibly since the first introduction of the Old-World species of B. nigra, B. rapa, B. napus, and $B$. geniculata (syn. $H$. incana) to California from Europe in the early 19th century.

Genetic (RFLP) variation within $X$. campestris first was described by Alvarez et al. (1). Three RFLP haplotypes of $X$. campestris generally corresponded to serological groups, and $X$. campestris pv. armoraciae strains were placed in an isolated

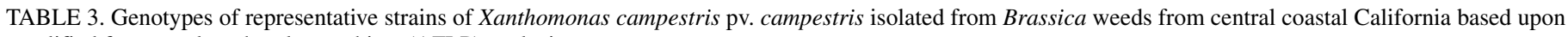
amplified fragment length polymorphism (AFLP) analysis

\begin{tabular}{|c|c|c|c|c|}
\hline \multicolumn{3}{|c|}{ X. campestris pv. campestris } & \multirow[b]{2}{*}{ Number of strains/site no. $\left(\mathrm{c}\right.$ or nc) ${ }^{\mathrm{c}}$} & \multirow[b]{2}{*}{ Location } \\
\hline Genotype $^{a}$ & Site $^{b}$ & Strain no. & & \\
\hline A & 15 & 1 & $1 / 15(\mathrm{nc})$ & Arroyo Grande, U.S. 101, El Campo \\
\hline A & 25 & 1,4 & $2 / 25(\mathrm{nc})$ & Moro Bay, San Luis Obispo, U.S. 1 \\
\hline A & 27 & $2,6,9,10,11,13$ & $6 / 27(\mathrm{nc})$ & Cayucos, U.S. 1 \\
\hline A & 28 & 1 & $1 / 28(\mathrm{nc})$ & Harmony, U.S. 1 \\
\hline A & 29 & $5,6,8$ & $3 / 29(\mathrm{nc})$ & Pt. Lopez Vista Point, U.S. 1 \\
\hline A & 40 & $2,3,4$ & $3 / 40(\mathrm{c})$ & Gonzales, Gloria Rd. \\
\hline A & 53 & $1,2,4$ & $3 / 53(\mathrm{nc})$ & Milpitas, Calaveras, Evans Road \\
\hline B & 14 & 1 & $1 / 14(\mathrm{nc})$ & Gaviota, U.S. 101 \\
\hline $\mathrm{B}$ & 30 & 1,2 & $2 / 30(\mathrm{nc})$ & Big Sur, U.S. 1 \\
\hline \multirow[t]{4}{*}{$\mathrm{B}$} & 33 & $1,2,4,5$ & $7 / 33$ (nc) & Garrapata Beach, U.S. 1 \\
\hline & $66^{\mathrm{d}}$ & 2 & $\ldots$ & $\ldots$ \\
\hline & $69^{d}$ & 4 & $\ldots$ & $\ldots$ \\
\hline & 86 & 9 & $\ldots$ & $\ldots$ \\
\hline B & 42 & 3 & $1 / 42(\mathrm{nc})$ & Gonzales, State Hwy 146 \\
\hline $\mathrm{C}$ & 39 & $1,2,3,4$ & $4 / 39(\mathrm{c})$ & Gonzales, Camphora, Gloria Road \\
\hline $\mathrm{C}$ & 42 & 2,4 & $2 / 42(\mathrm{nc})$ & Gonzales, State Hwy 146 \\
\hline $\mathrm{C}$ & 29 & 2,3 & $2 / 29(\mathrm{nc})$ & Pt. Lopez Vista Point, U.S. 1 \\
\hline $\mathrm{C}$ & 34 & $1,2,3$ & $3 / 34(\mathrm{nc})$ & Salinas River Beach \\
\hline $\mathrm{C}$ & 37 & $1,2,3,4 \mathrm{c}$ & $4 / 37(c)$ & Salinas, Old Stage Road \\
\hline $\mathrm{D}$ & 44 & $1,2,3,4$ & $4 / 44(\mathrm{c})$ & Soledad, River Road \\
\hline $\mathrm{E}$ & 54 & $2,3,4,5$ & $4 / 54(\mathrm{c})$ & Pleasanton, I-680, I-580, Bernal Road \\
\hline $\mathrm{E}$ & 55 & $1,2,3$ & $3 / 55(c)$ & Dixon, I-80 \\
\hline $\mathrm{F}$ & 20 & 1 & $1 / 20(\mathrm{c})$ & Lompoc, Vandenberg \\
\hline $\mathrm{F}$ & 47 & 1 & $1 / 47(\mathrm{c})$ & Hollister, Hwys 25 and 156 \\
\hline $\mathrm{F}$ & 48 & 1 & $1 / 48(\mathrm{c})$ & San Juan Road, Hwys 129 and 101 \\
\hline $\mathrm{F}$ & 49 & $\mathrm{sp}, 1,1 \mathrm{~A}$ & $3 / 49(\mathrm{nc})$ & Aptos, Sea Cliff Beach \\
\hline $\mathrm{F}$ & 51 & $1,2,4$ & $3 / 51(\mathrm{nc})$ & Santa Cruz Lighthouse Beach \\
\hline $\mathrm{G}$ & 36 & 1 & $1 / 36(\mathrm{c})$ & Salinas, Hwy 101, Potter \\
\hline $\mathrm{G}$ & 51 & LS1, LS2 & $23 / 51(\mathrm{nc})$ & Santa Cruz Lighthouse Beach \\
\hline G & 52 & LS2 & $1 / 52(\mathrm{nc})$ & Natural Bridges Beach \\
\hline Total & $\ldots$ & 68 & $\ldots$ & $\ldots$ \\
\hline
\end{tabular}

a Genotype based on consensus grouping by $k$-means analysis in over half of AFLP runs with different strain sets.

b Site locations shown in Figure 1.

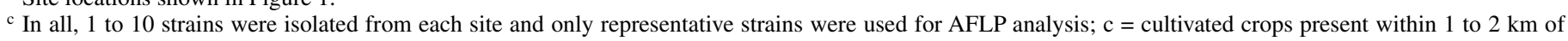
collection site or crops previously grown in the area; $\mathrm{nc}=$ noncultivated area with no history of crops within 20 or more km, most often along a roadside between the ocean and the cattle-grazing area along the foothills.

d Strains labeled 66 and 69 were isolated from site 332 weeks earlier (B. Oliver, personal communication). 
cluster. In a study of the diversity among strains of $X$. campestris in commercial crops in Tanzania, Massomo et al. (11) observed considerable diversity based upon BOX-PCR. They recognized seven genotypes among the 76 strains studied, with genotype 1 being predominant $(70 \%$ of total number of strains). Despite the uniform BOX genotype, 21 of 53 strains of the group $1(40 \%)$ were variable in biochemical properties (Biolog), 25 strains
(47\%) were different in rep-PCR profile, and 33 strains (63\%) were diverse in FAME analysis (11). Zhao et al. (31) found that the majority of 45 local strains of $X$. campestris from Oklahoma belonged to a single BOX genotype similar to a known crop strain, PHW117, representative for the haplotype $1(1,26)$. Group $\mathrm{B}$ was similar to the type strain NCPPB $528^{\mathrm{T}}$ of the haplotype 3 $(1,26)$, and five strains belonged to "exotic" groups C, D, and E

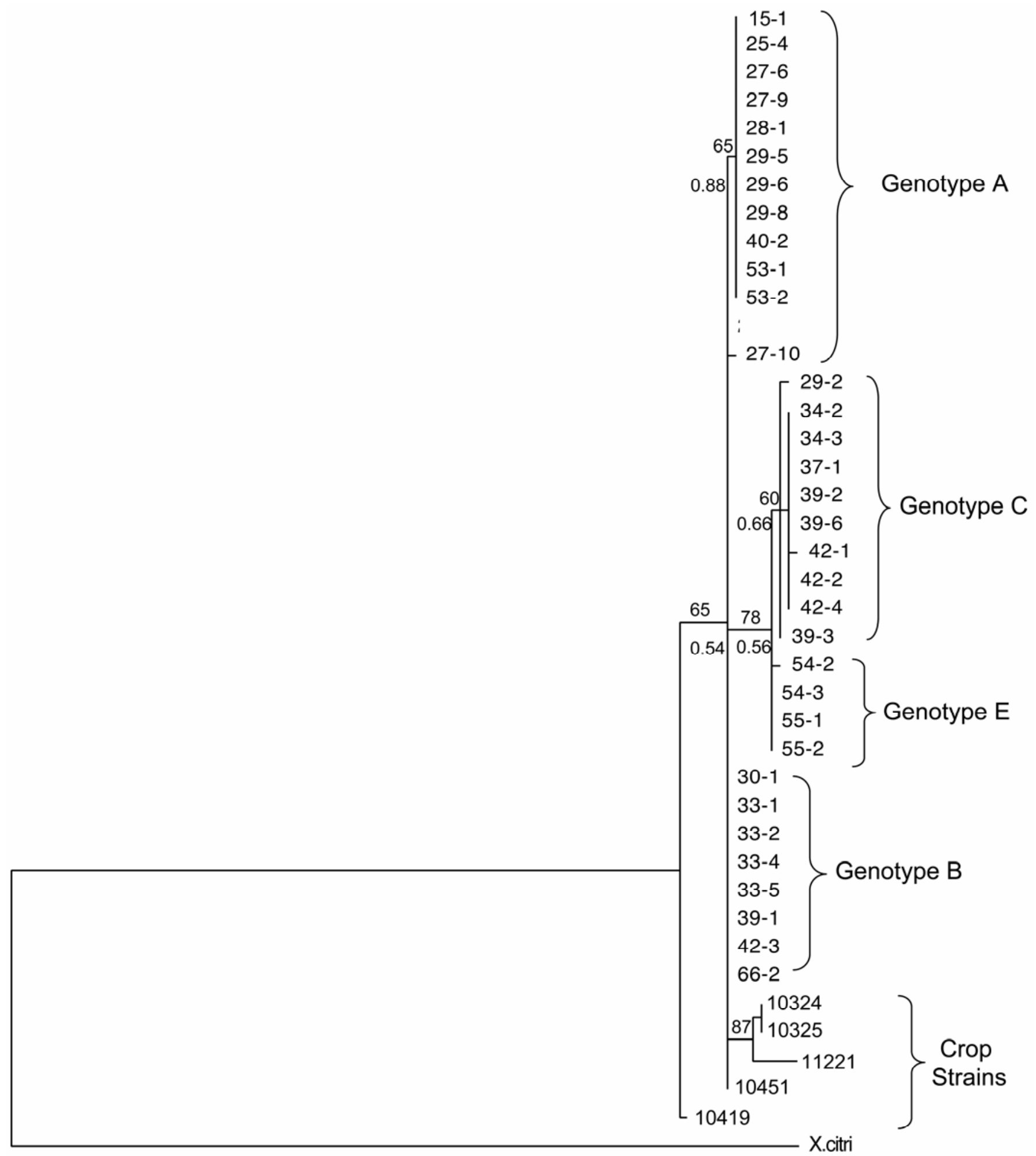

-0.001 substitutions/site

Fig. 4. Maximum likelihood phylogeny of Xanthomonas campestris pv. campestris weed strains, genotypes A, B, C, and E, and five known crop strains using a GTR + I model of molecular evolution for a concatenated dataset of three genes and 1,620 bp. Bootstrap support $(n=500)$ at $\geq 50 \%$ is placed above the branch and the Bayesian probability is placed below. Weed strain genotypes D, F, and G are not represented. 
from the United States and East Asia. Biolog results failed to correlate with pathovars or genotype grouping for the Oklahoma strains (31). Tsygankova et al. (26) grouped $X$. campestris strains from cultivated plants collected all over the world by rep-PCR profile into clusters corresponding to haplotypes 1 and 3 (1), and a third cluster was composed of leafspot pathovars, exotic strains from Japan, and strain 11216 from the United States. Thus, several independent studies repeatedly demonstrated the existence of two genetically narrow subgroups (haplotype 1 and 3 of Alvarez et al.) (1) of black rot pathogen distributed over the world on cultivated brassicas, and a more diverse native population with similarity to other pathovars of $X$. campestris.

Based upon AFLP and sequence analysis, the population of $X$. campestris found in Brassica weeds growing in the coastal California non-crop-production areas generally was genetically distinct and site specific. Sites 29, 39, and 42 contained multiple genotypes: A and C, B and C, and B and C, respectively. Also, all the genotypes found in weeds, whether grown in production $(C$, $\mathrm{D}$, and $\mathrm{E}$ ) or nonproduction ( $\mathrm{A}$ and $\mathrm{B}$ ) areas, were quite different. These results suggest that the population of $X$. campestris in weeds along the California coast generally has not moved from their geographic isolation along the coast into weeds or commercial crops grown in inland valleys. None of the 13 known crop strains of $X$. campestris included in the AFLP study or the 5 used in the sequence analysis typed with a coast genotype. Genotype A, dominant along the coast, was found in only two inland sites, 40 and 53.

All AFLP and sequence analysis branches containing weed strains showed a $65 \%$ or greater similarity. In comparison, $X$. citri subsp. citri (included as an out group) showed a similarity of $\leq 20 \%$ to both crop and weed strains. These results agree favorably to an AFLP species level similarity of $\geq 55 \%$ for Xanthomonas $(15,16)$ and Aeromonas (5) spp.

The original source of $X$. campestris in the weed population along the coast is unknown. All the cruciferous species from which we isolated $X$. campestris were introduced into California from Europe (13). One explanation for the original source of the weed population of $X$. campestris along coastal California is the possible introduction in the early 1800 s by Spanish missionaries. Crucifer plants apparently were used to mark the roads between the missions established along the California coast. All our attempts to obtain strains of $X$. campestris isolated from plants in Europe in the early 1900s were unsuccessful. These coastal weed strains should prove useful for studying the evolution of $X$. campestris. It would be especially interesting to determine the genotype of strains of $X$. campestris from populations of weeds along the Atlantic coast of Portugal and Spain and the Pacific Ocean in Mexico.

\section{ACKNOWLEDGMENTS}

The use of trade, firm, or corporation names in this publication (or page) is for the information and convenience of the reader. Such use does not constitute an official endorsement or approval by the U.S. Department of Agriculture or the Agricultural Research Service of any product or service to the exclusion of others that may be suitable. We thank D. Opgenorth for providing a culture of $X$. campestris isolated from site 33; $\mathrm{S}$. Koike for providing two strains of $X$. campestris isolated from Brussels sprouts from Castroville near site 33; Beijo Seed Company (Oceano, CA) for supplying cabbage seed for race determination; P. Randhawa, California Plant and Seed Laboratory (Eleverta, CA), for providing facilities for isolations; and the USDA Eastern Regional Research Center for sequencing. This research was supported in part by International Science and Technology Center grant no. 3431. We thank R. Sterner, The John Hopkins Applied Physics Laboratory, for use of the shaded relief map of California.

\section{LITERATURE CITED}

1. Alvarez, A. M., Benedict, A. A., Mizumoto, C. Y., Hunter, J. E., and Gabriel, D. W. 1994. Serological, pathological, and genetic diversity among strains of Xanthomonas campestris infecting crucifers. Phytopathology 84:1449-1457.

2. Castaneda, A., Reddy, J. D., El-Yacoubi, B., and Gabriel, D. W. 2005. Mutagenesis of all eight avr genes in Xanthomonas campestris pv. campestris had no detected effect on pathogenicity, but one avr gene affected race specificity. Mol. Plant-Microbe Interact. 18:1306-1317.

3. Hall, T. A. 1999. BioEdit: a user-friendly biological sequence alignment editor and analysis program for Windows 95/98/NT. Nucleic Acids. Symp. Ser. 41:95-98.

4. Huelsenbeck, J. P., and Ronquist, F. 2001. MRBAYES: Bayesian inference of phylogeny. Bioinformatics 17:754-755.

5. Huys, G., Coopman, R., Janssen, P., and Swings, J. 1996. High resolution genotyping analysis of the genus Aeromonas by AFLP fingerprinting. Int. J. Syst. Microbiol. 46:572-580.

6. Ignatov, A. N, Kuginuki, Y., and Hida, K. 1998. Black rot of crucifers and sources of resistance in brassicas. Jpn. Agric. Res. Q. 32:167-172.

7. Ignatov A. N., Monakhos, G. F., Dzhalilov, F. S., and Pozmogova, G. V. 2002. A virulence gene from Xanthomonas campestris pv. campestris homologous to the avrBs 2 locus is recognized in race-specific reaction by two different resistance genes in Brassica plant species. Genetika 38:1656-1662. (In Russian)

8. Kamoun, S., Kadmar, H. V., Tola, E., and Kado, C. I. 1992. Incompatible interaction between crucifers and Xanthomonas campestris involves a vascular hypersensitive response, role of the hrpX locus. Mol. PlantMicrobe Interact. 5:22-33.

9. Kuan, T.-L., Minsavage, G. V., and Schaad, N. W. 1986. Aerial dissemination of Xanthomonas campestris pv. campestris from crucifer weeds. Plant Dis. 70:409-413.

10. Manly. B. F. J. 1985. The Statistics of Natural Selection. Chapman \& Hall, London.

11. Massomo, S. M. S., Nielsen, H., Mabagala, R. B., Mansfeld-Giese, Hockenhull, J., and Mortensen, C. N. 2003. Identification and characterization of Xanthomonas campestris pv. campestris strains from Tanazania by Biolog, rep-PCR and fatty acid methyl ester analysis. Eur. J. Plant Pathol. 109:775-789.

12. McQueen, J. 1967. Some methods for classification and analysis of multivariate observations. Pages 281-297 in: Proc. 5th Berkeley Symp. I.

13. Munz, P. A., and Keck, D. D. 1963. A California Flora. University of California Press, Berkeley.

14. Nei, M., and Kumar, S. 2000. Molecular Evolution and Phylogenetics. Oxford University Press, New York.

15. Rademaker J. L., Hoste, B., Louws, F. J., Kersters, K., Swings, J., Vauterin, L., Vauterin, P., and de Bruijn, F. J. 2000. Comparison of AFLP and rep-PCR genomic fingerprinting with DNA-DNA homology studies: Xanthomonas as a model system. Int. J. Syst. Evol. Microbiol. 2:665-677.

16. Rademaker, J. L., Louws, F. J., Schultz, M. H., Rossbach, U., Vauterin, L., Swings, J., and de Bruijn, F. J. 2005. A comprehensive species to strain taxonomic framework. Phytopathology 95:1098-1111.

17. San Diego Museum of Natural History. (http://www.sdnhm.org/research/ botany/sdplants/brassicaceae.html)

18. Schaad, N. W., and Alvarez, A. 1993. Xanthomonas campestris pv. campestris: cause of black rot of crucifers. Pages 51-55 in: Xanthomonas. J. G. Swings and E. L. Civerolo, eds. Chapman \& Hall, London.

19. Schaad, N. W., and Dianese, J. C. 1981. Cruciferous weeds as a source of inoculum of Xanthomonas campestris in black rot of crucifers. Phytopathology 71:1215-1220.

20. Schaad, N. W., Jones, J. B., and Lacy, G. H. 2001. Xanthomonas. In: Laboratory Guide for Identification of Plant-Pathogenic Bacteria, 3rd ed. N. W. Schaad, J. B. Jones, and W. Chun, eds. American Phytopathological Society Press, St. Paul, MN

21. Shaad, N. W., Postnikova, E., Lacy, G. H., Sechler, A., Agarkova, I., Stromberg, P. E., Stromberg, V. K., and Vidaver, A. K. 2005. Reclassification of Xanthomonas campestris pv. citri (ex Hasse 1915) Dye 1978 forms A; B, C, D; and E as X. smithii subsp. citri (ex Hasse) sp. nov. nom. rev. comb. nov.; X. fuscans subsp. aurantifolii (ex Gabriel 1987 ) sp. nov. nom. rev. comb. nov.; and X. alfalfae subsp. citrumelo sp. nov. nom. rev. comb. nov.; X. campestris pv. malvacearum (ex Smith 1901) Dye 1978 as X. smithii subsp. smithii sp. nov. comb. nov, nom. nov.; X. campestris pv. alfalfae (ex Riker and Jones, 1935) Dye 1978 as X. alfalfae subsp. alfalfae (ex Ricker et al., 1935) sp. nov. nom. rev. and "var. fuscans" of X. campestris pv. phaseoli (ex Smith, 1897) Dye 1978 as $X$. fuscans subsp. fuscans sp. nov. Syst. Appl. Microbiol. 28:494-518.

22. Schaad, N. W., Postnikova, E., Lacy, G. H., Sechler, A., Agarkova, I., Stromberg, P. E., Stromberg, V. K., and Vidaver, A. K. 2006. Emended classification of xanthomonad pathogens on citrus. Syst. Appl. Microbiol. 29:690-695.

23. Schuenzel, E. L., Scally, M., Stouthamer, R., and Nunney, L. 2005. A multi-gene phylogenetic study of clonal diversity and divergence in North American strains of the plant pathogen Xylella fastidiosa. Appl. Environ. Microbiol. 71:3832-3839. 
24. Swofford, D. L. 2002. PAUP*. Phylogenetic Analysis Using Parsimony (* and Other Methods), Version 4. Sinauer Associates, Sunderland, MA

25. Taylor, J. D., Conway, J., Roberts, S. J., Astley, D., and Vicente, J. G. 2002. Sources and origin of resistance to Xanthomonas campestris pv. campestris in Brassica genomes. Phytopathology 92:105-111.

26. Tsygankova, S. V., Ignatov, A. N., Boulygina, E. S., Kuznetsov, B. B., and Korotkov, E. V. 2004. Genetic relationships among strains of Xanthomonas campestris pv. campestris revealed by novel rep-PCR primers Eur. J. Plant Pathol. 110:845-853.

27. Vicente, J., Conway, J., Roberts, S. J., and Taylor, J. D. 2001. Identification and origin of Xanthomonas campestris pv. campestris races and related pathovars. Phytopathology 91:492-499.
28. Vos, P., Hogers, R., Bleeker, M., Reijans, M., van de Lee, T., Hornes, M., Frijters, A., Pot, J., Peleman, J., and Kuiper, M. 1995. AFLP: A new technique for DNA fingerprinting. Nucleic Acids Res. 23:4407-4414.

29. Williams, P. H. 1980. Black rot: A continuing threat to world crucifers. Plant Dis. 64:736-742.

30. Yeh, F. C., Yang, R.-C., Boyle, T., Ye, Z.-H., and Mao, J. X. 1997. Popgene, the user-friendly shareware for population genetic analysis. Molecular Biology and Biotechnology Centre, University of Alberta, Canada.

31. Zhao, Y., Damicone, J. P., Demezas, D. H., and Bender, C. L. 2000 Bacterial leaf spot diseases of leafy crucifers in Oklahoma caused by pathovars of Xanthomonas campestris. Plant Dis. 84:1008-1014. 